\title{
Phytochemical composition, antilipidemic and antihypercholestrolemic perspectives of Bael leaf extracts
}

\author{
Nosheen Asghar ${ }^{1}$, Zarina Mushtaq ${ }^{1 *}$, Muhammad Umair Arshad ${ }^{2}$, Muhammad Imran², Rabia Shabir Ahmad \\ and Syed Makhdoom Hussain ${ }^{3}$
}

\begin{abstract}
Background: In recent times, focus on plant research has improved all over the world and essential parts of plants provide bioactive compounds in human diet. The bael (Aegle marmelos) has enormous traditional uses in the treatment of chronic diarrhea, dysentery, peptic ulcers and as a laxative. The main focus of this study was characterization of bael leaf extract for its bioactive constituents, antihypercholestrolemic and antilipidemic perspectives.

Methods: After proximate composition of bael powder, the aqueous extract of bael leaf was used for phytochemical profiling (alkaloids, total phenolic content and total flavonoid content). Afterwards, normal rats group $G_{0}$ was administrated basal diet while $G_{1}$ and $G_{2}$ normal rat groups were fed diets containing bael leaf extract $125 \mathrm{mg}$ and $250 \mathrm{mg}$, respectively for consecutive 60 days. In a similar way, hyperlipidemic rats group $\mathrm{G}_{\mathrm{ho}}$ was administrated basal diet while $G_{h 1}$ and $G_{h 2}$ hyperlipidemic rat groups were fed diets containing bael leaf extract $125 \mathrm{mg}$ and $250 \mathrm{mg}$, respectively for consecutive 60 days. The blood drawn on day 0, day 30 and day 60 was analyzed for serum parameters, such as total cholesterol, high-density lipoprotein cholesterol, low-density lipoprotein cholesterol, triglycerides concentration and free and ester cholesterol.

Results: Bael leaf powder is a rich source of crude fiber $(14.50 \pm 0.10 \mathrm{~g} / 100 \mathrm{~g})$. Aqueous extract of bael leaf contains alkaloids (15.58 $\pm 0.05 \mathrm{mg} / \mathrm{g}$ ), flavonoids (64.00 $\pm 0.05 \mathrm{mg} / \mathrm{g}$ ), phenolics (30.34 $\pm 0.01 \mathrm{GAEmg} / \mathrm{g})$. From the In vivo studies, the lowest weight gain was observed in group $G_{2}$ and in $G_{h 2}$ as compared to control of both groups. The decrease in serum TC for $G_{1}-15.06 \%, G_{2}-17.27 \%$ while in $G_{h_{1}}-22.46 \%$ and $G_{h 2}-34.82 \%$ after day 60 , respectively. The maximum decrease was observed in group $G_{2}(-14.33 \%)$ and in $G_{h 2}(-24.79 \%)$ for triglycerides after 60 days. For HDL-cholesterol, significant increase (11.20\%) in $G_{2}$ and (49.83\%) in $G_{h 2}$ was observed of after 60 days. A trend in decrease of serum LDL-cholesterol in $G_{2}(-9.63 \%)$ and in $G_{h 2}(-44.65 \%)$ was also observed at day 60 , and $-19.05 \%$ and $-30.06 \%$ decrease was noted in $G_{2}$ and $G_{h 2}$, respectively and decreasing trend was observed in free and total cholesterol $-22.30 \%$ and $-81.49 \%$ for groups $G_{2}$ and $G_{h 2}$ after day 60 .
\end{abstract}

Conclusions: The results of the present study demonstrated that the extract contents of bael leaf provide protective role against hypercholesterolemic and hyperlipidemic conditions.

Keywords: Aegle marmelos, Bael, Water extract, Alkaloids, Phenolics, Hypercholesterolemia, Hyperlipidemia

\footnotetext{
*Correspondence: zee_ft@hotmail.com

1 Department of Food Science, Nutrition and Home Economics, Government

College University, Faisalabad, Pakistan

Full list of author information is available at the end of the article
} 


\section{Background}

In recent times, focus on plant research has improved all over the world and increasing number of studies have demonstrated potential health benefits of medicinal plants used in numerous traditional systems. It has been shown that many parts of plants for example leaves, stems, roots, fruits, and seeds provide health and nutrition providing bioactive compounds in human diet [1]. The bael (Aegle marmelos) has enormous traditional uses in the treatment of chronic diarrhea, dysentery, peptic ulcers and as a laxative. Past studies depicted antifungal, antibacterial, antiprotozoal and hypoglycemic properties where-as its cardiac effect has been investigated effectively as bael leaf extract in lower doses increases both heart rate and amplitude of contraction while in higher doses transiently inhibit the heart, followed by further stimulation [2].

Bael is a slow growing medium sized tree, up to $15 \mathrm{~m}$ tall with short trunk, thick, flaking bark, sometimes spiny branches, the lower ones drooping [3]. The deciduous alternate leaves, singly, two or three, are composed of 3 to 5 oval, pointed leaflets 4 to $10 \mathrm{~cm}$ long, 2 to $5 \mathrm{~cm}$ wide, the terminal one with a long petiole [4]. Bael is known for its medicinal properties, especially, the leaves and fruits which has shown cardiac and circulatory stimulatory activities. Bael extract has protective effect against jaundice, also shown astringent and carminative activities. Bael leaf extract is also effective against thyroid related disorder and swelling of joints. It has also been reported to possess anti-diabetic, antimicrobial, antifungal, cardioprotective, antiulcer, antihyperlipidemic effects, and are commonly used for the treatment of different ailment in the indigenous system of medicine in the Asian sub-continent [5].

Different types of carotenoids have been reported in the bael, which are responsible for the imparting yellow pale colour to fruit. Minor constituents such as ascorbic acid, sitosterol, crude fiber, tannins, $\alpha$ - amyrin, carotenoids, and crude proteins are also present. More than 100 bioactive compounds have been isolated from different parts of this plant. Various phytochemicals that have been extracted from leaf part of this plant are Skimmianine, Aeglin, Rutin, $\gamma$-sitosterole, $\beta$-sitosterol, Flavone, Lupeol, Cineol, Citral, Glycoside, O-isopentenyl, Hallordiol, Mameline, Citronellal, Cuuminaldehyde phenylethyle cinnamamides, Euginol, Marmesinin, Aegelin, Glycoside have been shown to be biologically active against various major and minor diseases [6].

Bael leaf extract contains alkaloids, emodins, ferric chloride, lead acetate, gelatin, phenolics, and volatile oils which may exhibit potential anticholesterol activity. The plant materials have these useful properties, which can be used for numerous medicinal applications and can be used by pharmaceutical company. Hyperlipidemia is a serious health problem and greatest cause of death all over the world, and if not treated, it is responsible for many complications affecting various organs in the body [7]. Hyperlipidemia may be treated using antilipidemic drugs but the hyperlipidemia originating from diabetes, renal lipid nephrosis or hypothyroidism necessitates the treatment of the original disease rather than hyperlipidemia [8]. The findings of the study of Sinha et al. [9] revealed that ethanolic extracts of bael leaves can effectively control the blood cholesterol and triglycerides levels in dyslipidaemic conditions. Oral administration of aqueous extract of bael fruits, leaves and seeds separately to a dose of $250 \mathrm{mg} / \mathrm{kg}$ to streptozotocin induced diabetic rats significantly lowered the serum and tissue lipid profile $[10,11]$. The main objectives of this study were characterization of bael leaf extract for its bioactive constituents, antihypercholestrolemic and antilipidemic perspectives.

\section{Methods \\ Procurement of material}

Fully ripe fresh bael (Aegle marmelos Linn.) leaves, without any visual defects, were collected from University of Agricultural Faisalabad, Pakistan. Bael leaves were washed by water to remove dust/debris and dried at $50{ }^{\circ} \mathrm{C}$, followed by grinding to a coarse powder consistency [12] and stored at $-20{ }^{\circ} \mathrm{C}$ until used.

\section{Aqueous extraction}

Bael leaves, after washing, thoroughly were hot air-dried for 3 days at room temperature $\left(\begin{array}{lll}\sim 25 & C\end{array}\right)$. The dried leaves were pulverized using pestle mortar to obtain a powdered form which was stored in airtight glass vials at $4 \mathrm{C}$ until used. The powdered plant material was mixed with distilled water (1:5) and stirred overnight at room temperature. The residue was removed by filtration through Whatman no.1 filter paper and the aqueous extracts was lyophilized and stored in airtight glass vials [13]. All extracts were stored in sterilized containers at $-20{ }^{\circ} \mathrm{C}$ until used for testing.

All extraction and subsequent analyses were done using three replicates.

\section{Chemical composition}

The powder of bael leaf was chemically estimated. Moisture content was analyzed by using air forced draft oven. The sample was dried at $105 \pm 5^{\circ} \mathrm{C}$ to constant weight and calculations was made [14] (AACC Method No. 44-15A). For determination of crude protein, nitrogen percentage was assessed through Kjeltech Apparatus. The protein was calculated by multiplying percent nitrogen with conversion factor, 6.25 [15] (AOAC Method No. 990.03). Crude fat was estimated in oven-dried sample by Soxtec System. Sample weighing $5 \mathrm{~g}$ was used for 
extraction of crude fat with petroleum ether. After extraction, residue was dried till constant weight [14] (AACC Method No. 30-10). After fat extraction, samples were examined for crude fiber through Labconco Fibertech. Two $\mathrm{g}$ of fat-free sample was digested firstly with $1.25 \% \mathrm{H}_{2} \mathrm{SO}_{4}$ and finally with $1.25 \% \mathrm{NaOH}$ for $30 \mathrm{~min}$. The residue was dried and weighed followed by ignition at $550 \pm 15^{\circ} \mathrm{C}$ and cooled for further calculations [15] (AOAC Method No. 978.10). For determination of ash content, sample was taken in pre-weighed crucible and charred on burner till no visible fumes before incineration in the Muffle Furnace to obtain white grayish residue with no other taints [14] (AACC Method No. 08-01).

\section{Phytochemical profiling Determination of alkaloids}

Alkaloids content were measured by following the method of Harborne [16]. A suspension was prepared by dispersing $5 \mathrm{~g}$ of the dried leaves in $10 \%$ acetic acid solution in ethanol and kept at $28{ }^{\circ} \mathrm{C}$ for $4 \mathrm{~h}$ which was further filtered through Whatman number. 42. Thereafter, alkaloid was precipitated by concentrating the filtrate to one-fourth of its original volume and drops of conc. Aqueous $\mathrm{NH}_{4} \mathrm{OH}$ were added. Finally, the precipitate was washed with $1 \%$ ammonia solution and dried at $80^{\circ}$ $\mathrm{C}$ in the oven. The content of alkaloid was calculated and expressed as $\mathrm{mg} / \mathrm{g}$ dry weight basis.

\section{Determination of flavonoids}

The flavonoids content were determined by Harborne method [16]. Briefly, $5 \mathrm{~g}$ of leaves was boiled in $2 \mathrm{M}$ $\mathrm{HCl}$ for $30 \mathrm{~min}$ under reflux and filtered after cooling down to room temperature. Equal volume of ethyl acetate was then added drop-wise to the filtrate. The weight of precipitated flavonoids was determined and reported as $\mathrm{mg} / \mathrm{g}$ dry weight basis.

\section{Total phenolic content (TPC)}

TPC of extracts were determined using Folin-Ciocalteu's reagent method [17]. Briefly, $100 \mu \mathrm{l}$ of different aqueous extracts of bael leaf, $500 \mu \mathrm{l}$ of Folin-Ciocalteu's reagent and $1 \mathrm{ml}$ sodium carbonate were added and incubated at ambient temperature $\left(25-27^{\circ} \mathrm{C}\right)$ for $90 \mathrm{~min}$. The developed color was measured at $760 \mathrm{~nm}$ using UV-VIS spectrophotometer (UV-2450 PC, Shimadzu, Japan). Total phenolic content (TPC) were expressed as gallic acid equivalent (GAE $\mathrm{mg} / \mathrm{g}$ of dry mass.

\section{Efficacy studies}

\section{Experimental animals and diets}

The study program was designed after the review and approval of ethical guidelines set by parent institute. Male albino rats (age 80-90 days, body weight $170 \pm$
$10 \mathrm{~g})$ were purchased from the National Institute of Health, Islamabad, Pakistan. The rats were individually housed in stainless steel wire-bottom cages in an environmentally controlled room at $25 \pm 2{ }^{\circ} \mathrm{C}$ and $60 \pm 5 \%$ relative humidity with a $12 \mathrm{~h}$ light-dark cycle. All groups of rat received basal diet consisting of $65 \%$ starch, $10 \%$ casein, $10 \%$ corn oil, $3 \%$ salt mixture, $1 \%$ vitamins mixture and 10\% cellulose and addition of $1 \%$ cholesterol for induction of hyperlipidemia. At the initiation of study, rats $(n=10)$ were slaughtered to establish base line serum parameters. Hyperlipidemia was confirmed by measuring the levels of serum lipids and lipoproteins in the rats. Afterwards, normal rats group $G_{0}$ was administrated basal diet while $G_{1}$ and $G_{2}$ normal rat groups were fed diets containing bael leaf extract $125 \mathrm{mg}$ and $250 \mathrm{mg}$, respectively for consecutive sixty days. In a similar way, hyperlipidemic rats group $G_{h 0}$ was administrated basal diet while $G_{h 1}$ and $G_{h 2}$ hyperlipidemic rat groups were fed diets containing bael leaf extract $125 \mathrm{mg}$ and $250 \mathrm{mg}$, respectively for consecutive sixty days. Each group was comprised of 10 rat animals. The amount of diet consumed by each rat was determined by deducting the left-over and spilled diet from the total amount supplied per day [18]. Gain in body weight of individual rats was determined after 30 and 60 day intervals.

\section{Serum collection}

At day 0, 30 and 60, Blood samples were collected through cardiac puncture, and serum was collected following the method of Uchida et al. [19].

\section{Biochemical profile Serum lipid profile}

Serum cholesterol level was determined using CHODPAP method described by Stockbridge et al. [20]. High density lipoprotein (HDL) in serum samples was measured by HDL cholesterol precipitant method described by Assmann [21]. Serum samples were also analyzed for low density lipoproteins (LDL) following the procedure of McNamara et al. [22]. Total triglycerides in all serum samples were determined by liquid triglycerides (GPO-PAP) method as outlined by Annoni et al. [23].

\section{Estimation of free and ester cholesterol}

To $0.2 \mathrm{ml}$ of serum homogenate in a test tube, $3 \mathrm{ml}$ of acetone ethanol mixture was added and kept on a water bath to raise its temperature to $95{ }^{\circ} \mathrm{C}$. This mixture was vortexed for $15 \mathrm{~min}$ and the precipitated protein was separated by centrifugation. The protein precipitate was washed again with $3 \mathrm{ml}$ of acetone ethanol mixture and the supernatants were pooled. $1 \mathrm{ml}$ of glacial acetic acid was added, followed by a drop of $10 \%$ glacial acetic acid and the contents were mixed well. 
The tubes were securely closed and kept in a dark chamber for $16 \mathrm{~h}$. The precipitated cholesterol digitonide was removed by centrifugation at $1000 \times \mathrm{x}$ for $15 \mathrm{~min}$. The precipitate was then dissolved in $10 \mathrm{ml}$ of glacial acetic acid by heating over in a water bath. To this $1 \mathrm{ml}$ of isopropanol was added followed by $2 \mathrm{ml}$ of $0.1 \%$ ferric chloride solution and mixed well. After $5 \mathrm{~min}, 2 \mathrm{ml}$ of concentrated $\mathrm{H}_{2} \mathrm{SO}_{4}$ was added dropwise with constant shaking. The colour developed was read at $540 \mathrm{~nm}$ along with a standard cholesterol solution [24]. The esterified cholesterol was calculated from the difference between total and free cholesterol.

\section{Statistical analysis}

The average of the three samples was reported as the measured value with standard deviation. The Duncan's multiple range (DMR) test was used to estimate the level of significance that existed between the mean values for data analysis. The sample analysis for biochemical profile and study day intervals was carried out in triplicate and the significant differences were calculated among means at a probability level of 5\% using Minitab version 14.1 [25].

\section{Results}

Bael leaf power contained moisture content $6.80 \pm$ $0.40 \mathrm{~g} / 100 \mathrm{~g}$, crude protein $6.00 \pm 0.10 \mathrm{~g} / 100 \mathrm{~g}$, crude fat $1.95 \pm 0.10 \mathrm{~g} / 100 \mathrm{~g}$, crude fiber $14.50 \pm 0.10 \mathrm{~g} / 100 \mathrm{~g}$ and ash $9.40 \pm 0.10 \mathrm{~g} / 100 \mathrm{~g}$. The quantitative phytochemical estimation showed that the leaf contained a significant amount of alkaloids, flavonoids and phenolics. The mean values for these phytochemicals were: alkaloids $(15.58 \pm 0.05 \mathrm{mg} / \mathrm{g})$, flavonoids $(64.0 \pm 0.05 \mathrm{mg} / \mathrm{g})$ and phenolics $(30.34 \pm 0.01 \mathrm{mg} / \mathrm{g})$.

There was a significant decrease in body weight of hyperlipidemic group of rats with respect to normal group (Fig. 1). For normal group of rats, highest weight gain was observed in group $G_{0}$ followed by $G_{1}$, while the lowest increase was in group $G_{2}$ after 30 days. Same trend was recorded after 60-day for normal group of rats. For hyperlipidemic group, the highest weight gain was observed in group $G_{h 0}$, whereas, the lowest weight gain was noted in $G_{h 2}$ after 30 days. At the end of 60 day the highest weight gain was noted in group $G_{h 0}$ and the lowest in $G_{h 2}$ followed by $G_{h 1}$.

Lipid profile of normal and hyperlipidemic group rats was observed after 30 and 60 day of study trial (Table 1). After 30 days, the highest significant decrease of 8 . $88 \%$ was observed in group $G_{2}$ in normal rats whereas a significant decrease of $8.84 \%$ was noted in group $\mathrm{G}_{1}$. After 60 days, highly significant decrease was noted in group $G_{2}(-17.27 \%)$ and in group $G_{1}(-15.06 \%)$ in normal rats. In hyperlipidemic rat group, significant decrease was observed in rat groups. The decreasing trend was noted in $G_{h 1}(-11.91 \%)$ but lesser than $G_{h 2}(-17$. 49\%) after 30-day trial as compared to the control group. After 60 days, the cholesterol level was decreased significantly in $G_{h 1}(-22.46 \%)$ and $G_{h 2}(-34.82 \%)$ groups, respectively than values taken as base line.

A significantly lower triglycerides level was observed in normal groups $G_{1}$ and $G_{2}$ as compared to $G_{0}$ after 30 days (Table 2). In 60-day trial, the normal group of rats showed significant decrease in $G_{1}$ (rats fed on $125 \mathrm{mg}$ bael leaf extract) and $\mathrm{G}_{2}$ (rats fed on $250 \mathrm{mg}$ bael leaf extract) groups. However, triglyceride level for hyperlipidemic group was decreased in $G_{h 1}(11.99 \%)$ and $G_{h 2}(-14.01 \%)$ as compared to values taken as base line in first 30 days. After 60 days the highest decrease was noted in $G_{h 2}(-24.79 \%)$ than $G_{h 1}(-21.84 \%)$.

HDL cholesterol level showed significant differences in the normal and hyperlipidemic groups of rats. After

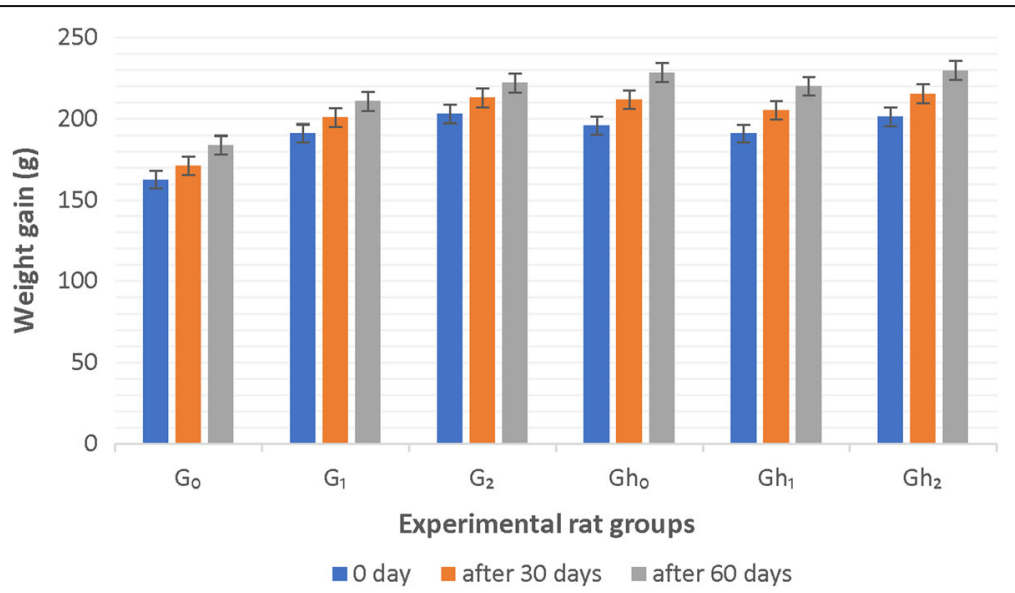

Fig. 1 Weight gain of various rat groups in 30 and 60 days of study trial ( $G_{0}$ : Control Normal rat group. $G_{1}$ : Normal rat group fed on 125 mg bael leaf extract. $\mathrm{G}_{2}$ : Normal rat group fed on $250 \mathrm{mg}$ bael leaf extract. $\mathrm{Gh}_{0}$ : Control Hyperlipidemic rat group. Gh; : Hyperlipidemic rat group fed on $125 \mathrm{mg}$ bael leaf extract. $\mathrm{Gh}_{2}$ : Hyperlipidemic rat group fed on $250 \mathrm{mg}$ bael leaf extract) 
Table 1 Cholesterol of various groups of rats in 60 days study trial

\begin{tabular}{|c|c|c|c|}
\hline \multirow[t]{2}{*}{ Rat Group } & \multicolumn{3}{|c|}{ Cholesterol (mg/dL) } \\
\hline & Day-0 & Day-30 & Day-60 \\
\hline \multicolumn{4}{|l|}{ Control } \\
\hline $\mathrm{G}_{0}$ & $96.56 \pm 2.43^{\mathrm{Aa}}$ & $97.13 \pm 2.52^{\mathrm{Aa}}$ & $97.01 \pm 2.78^{\mathrm{Aa}}$ \\
\hline $\mathrm{G}_{1}$ & $95.74 \pm 1.85^{\mathrm{Aa}}$ & $87.27 \pm 1.76^{\mathrm{Bb}}$ & $81.32 \pm 1.28^{B C}$ \\
\hline $\mathrm{G}_{2}$ & $97.11 \pm 1.71^{\mathrm{Aa}}$ & $88.48 \pm 1.39^{\mathrm{Bb}}$ & $80.33 \pm 1.49^{B C}$ \\
\hline \multicolumn{4}{|c|}{ Net Changes in Control Group } \\
\hline$G_{1}-G_{0}$ & $0.82 \pm 0.58^{c}$ & $9.86 \pm 0.76^{b}$ & $15.69 \pm 1.50^{\mathrm{a}}$ \\
\hline$G_{2} \cdot G_{0}$ & $0.55 \pm 0.72^{c}$ & $8.65 \pm 1.13^{b}$ & $16.68 \pm 1.29^{a}$ \\
\hline $\mathrm{G}_{2}, \mathrm{G}_{1}$ & $1.37 \pm 0.14^{c}$ & $1.21 \pm 0.37^{c}$ & $0.99 \pm 0.21^{c}$ \\
\hline \multicolumn{4}{|l|}{ HPL Group } \\
\hline $\mathrm{G}_{\mathrm{ho}}$ & $194.86 \pm 2.93^{\mathrm{Ca}}$ & $240.34 \pm 2.48^{\mathrm{Ba}}$ & $279.42 \pm 2.26^{A}$ \\
\hline$G_{h 1}$ & $193.94 \pm 3.81^{\mathrm{Aa}}$ & $170.84 \pm 2.21^{\mathrm{Bb}}$ & $150.37 \pm 2.08^{\mathrm{BC}}$ \\
\hline$G_{h 2}$ & $195.50 \pm 3.74^{\mathrm{Aa}}$ & $161.29 \pm 2.98^{B C}$ & $127.41 \pm 2.35^{\mathrm{Cc}}$ \\
\hline \multicolumn{4}{|c|}{ Net Changes in HPL Group } \\
\hline$G_{h 1}-G_{h 0}$ & $0.92 \pm 0.88^{9}$ & $69.50 \pm 0.58^{d}$ & $129.05 \pm 0.18^{b}$ \\
\hline$G_{h 2}-G_{h 0}$ & $0.64 \pm 0.81^{9}$ & $79.05 \pm 0.50^{c}$ & $152.01 \pm 0.09^{a}$ \\
\hline$G_{h 2}-G_{h 1}$ & $1.56 \pm 0.07^{9}$ & $9.55 \pm 0.77^{f}$ & $22.96 \pm 0.27^{e}$ \\
\hline
\end{tabular}

Mean \pm Standard Deviation; $n=10$

$\mathrm{G}_{0}$ : Control Normal rat group. $\mathrm{G}_{1}$ : Normal rat group fed on $125 \mathrm{mg}$ bael leaf extract. $\mathrm{G}_{2}$ : Normal rat group fed on $250 \mathrm{mg}$ bael leaf extract $\mathrm{G}_{\mathrm{h} 0}$ : Control Hyperlipidemic rat group. $\mathrm{G}_{\mathrm{h} 1}$ : Hyperlipidemic rat group fed on $125 \mathrm{mg}$

bael leaf extract. $\mathrm{G}_{\mathrm{h} 2}$ : Hyperlipidemic rat group fed on $250 \mathrm{mg}$ bael leaf extract HPL: Hyperlipidemic group of rats

Means showing different lower case letters $(a, b, c, d, e, f, g)$ represent significant differences $(p<0.05)$ within control or HPL groups. Whereas, means showing different upper case letters $(A, B, C)$ represent significant differences $(p<0.05)$ across day-0 through day-60

30 days, there was no specific change was seen in normal group of rats as compared to the values taken as base line. After 60 days, the increasing trend was noted in $G_{2}$ than $G_{1}$ as compared to control group. For hyperlipidemic group of rats, the highest increase was noted in $G_{h 2}$ than $G_{h 1}$ after 30 days. After 60-days, the maximum increasing trend was seen in $G_{h 2}$ than $G_{h 1}$, respectively (Table 3 ).

The LDL was increased from normal level after giving basal diet along with additional cholesterol (Table 4), however, after administration of bael leaf extract it showed a significant decrease in LDL level of rats. Decrease was noted in normal group $\left(G_{1}\right.$ and $\left.G_{2}\right)$ after 30 days $(-2.44 \%$ to $-4.59 \%)$ and 60 days $(-4.96 \%$ to $9.63 \%$ ) of study according to the values taken as base line whereas the decrease was noted after 30 to 60 day while the decrease was higher in hyperlipidemic group $\left(G_{h 1}\right.$ and $\left.G_{h 2}\right)-16.06 \%$ and $-20.15 \%$ after ay 30 . After 60 days the LDL values had dropped down close to normal levels.

Free cholesterol was elevated in cholesterol fed rats as compared to the normal group. But in normal group of
Table 2 Triglycerides of various groups of rats in 60 days study trial

\begin{tabular}{|c|c|c|c|}
\hline \multirow[t]{2}{*}{ Rat Groups } & \multicolumn{3}{|c|}{ Triglycerides (mg/dL) } \\
\hline & Day-0 & Day-30 & Day-60 \\
\hline \multicolumn{4}{|l|}{ Control } \\
\hline $\mathrm{G}_{0}$ & $101.61 \pm 1.28^{\mathrm{Bb}}$ & $102.74 \pm 1.56 b^{A B}$ & $104.08 \pm 1.72^{\mathrm{Aa}}$ \\
\hline $\mathrm{G}_{1}$ & $118.47 \pm 2.00^{\mathrm{Aa}}$ & $110.35 \pm 1.85^{\mathrm{aB}}$ & $103.75 \pm 2.48^{\mathrm{AC}}$ \\
\hline $\mathrm{G}_{2}$ & $93.98 \pm 2.11^{A c}$ & $82.86 \pm 2.04^{\mathrm{CB}}$ & $72.91 \pm 2.69^{B C}$ \\
\hline \multicolumn{4}{|c|}{ Net Changes in Control Group } \\
\hline $\mathrm{G}_{1}-\mathrm{G}_{0}$ & $16.86 \pm 0.72^{\mathrm{e}}$ & $7.61 \pm 0.29^{f}$ & $0.33 \pm 0.76^{9}$ \\
\hline $\mathrm{G}_{2}-\mathrm{G}_{0}$ & $7.63 \pm 0.83^{f}$ & $19.88 \pm 0.48^{d}$ & $31.17 \pm 0.97^{a}$ \\
\hline $\mathrm{G}_{2}-\mathrm{G}_{1}$ & $24.49 \pm 0.11^{c}$ & $27.49 \pm 0.19^{b}$ & $30.84 \pm 0.21^{a}$ \\
\hline \multicolumn{4}{|l|}{ HPL Group } \\
\hline $\mathrm{G}_{\mathrm{ho}}$ & $145.17 \pm 3.69^{c b}$ & $162.31 \pm 3.70^{\mathrm{Bb}}$ & $194.12 \pm 3.33^{\mathrm{Aa}}$ \\
\hline $\mathrm{G}_{\mathrm{h} 1}$ & $161.10 \pm 3.74^{\mathrm{Aa}}$ & $141.77 \pm 3.44^{\mathrm{Ba}}$ & $125.91 \pm 3.65^{\mathrm{BC}}$ \\
\hline $\mathrm{G}_{\mathrm{h} 2}$ & $160.59 \pm 2.62^{\mathrm{Aa}}$ & $138.09 \pm 2.40^{\mathrm{Ba}}$ & $120.77 \pm 2.34^{c c}$ \\
\hline \multicolumn{4}{|c|}{ Net Changes in HPL Group } \\
\hline$G_{h 1}-G_{h 0}$ & $15.93 \pm 0.05^{e}$ & $20.54 \pm 0.26^{d}$ & $68.21 \pm 0.32^{b}$ \\
\hline$G_{h 2}-G_{h 0}$ & $15.42 \pm 1.07^{e}$ & $24.22 \pm 1.30^{c}$ & $73.35 \pm 0.99^{a}$ \\
\hline$G_{h 2}-G_{h 1}$ & $0.51 \pm 1.12^{h}$ & $3.68 \pm 1.04^{\mathrm{g}}$ & $5.14 \pm 1.31^{f}$ \\
\hline
\end{tabular}

Mean \pm Standard Deviation; $n=10$

$\mathrm{G}_{0}$ : Control Normal rat group. $\mathrm{G}_{1}$ : Normal rat group fed on $125 \mathrm{mg}$ bael leaf extract. $\mathrm{G}_{2}$ : Normal rat group fed on $250 \mathrm{mg}$ bael leaf extract $\mathrm{G}_{\mathrm{h} 0}$ : Control Hyperlipidemic rat group. $\mathrm{G}_{\mathrm{h} 1}$ : Hyperlipidemic rat group fed on $125 \mathrm{mg}$

bael leaf extract. $\mathrm{G}_{\mathrm{h} 2}$ : Hyperlipidemic rat group fed on $250 \mathrm{mg}$ bael leaf extract HPL: Hyperlipidemic group of rats

Means showing different lower case letters $(a, b, c, d, e, f, g, h)$ represent significant differences $(p<0.05)$ within control or HPL groups. Whereas, means showing different upper case letters $(A, B, C)$ represent significant differences $(p<0.05)$ across day-0 through day- 60

rats, significant decrease was noted in $G_{1}$ and $G_{2}$ groups as compared to the control after 30 days, this decrease was two-fold higher in these groups after 60 days. Whereas, in the hyperlipidemic group of rats, elevated level of free cholesterols turned to a normal range after 60 days as a result of bael leaf extract in their diet (Table 5).

A significant change for ester cholesterol was observed after 60 days in normal rats as compared to the values taken as base line (Table 6). The decrease was $(-9.6 \%)$ and $(-11.52 \%)$ in groups $G_{1}$ and $G_{2}$ after 30 days while the decrease was $(-22 \%)$ and $(-22.30 \%)$ after 60 days of study. In hyperlipidemic rats, the significant reduction was recorded after 60 days. After 30 days rats, significant decrease, $-18.46 \%$ and $-34.26 \%$, was observed in groups $G_{h 1}$ and $G_{h 2}$ respectively. A decrease of $-34.94 \%$ and $59.89 \%$ was seen in $G_{h 1}$ and $G_{h 2}$, respectively.

\section{Discussion}

Various studies have been done to analyze the proximate composition of the bael parts, It was found that bael leaf, pulp and seed powder were good source of protein, fat, 
Table $3 \mathrm{HDL}$ of various groups of rats in 60 days study trial

\begin{tabular}{clll}
\hline Rat Groups & $\mathrm{HDL}(\mathrm{mg} / \mathrm{dL})$ & & \\
\cline { 2 - 4 } & Day-0 & Day-30 & Day-60 \\
\hline Control & & \\
$G_{0}$ & $49.53 \pm 0.36^{\mathrm{Bb}}$ & $52.89 \pm 0.44^{\mathrm{Aba}}$ & $51.05 \pm 0.24^{\mathrm{Ba}}$ \\
$G_{1}$ & $50.60 \pm 0.35^{\mathrm{Aa}}$ & $51.91 \pm 0.25^{\mathrm{Aa}}$ & $53.07 \pm 0.31^{\mathrm{Aab}}$ \\
$G_{2}$ & $49.07 \pm 0.67^{\mathrm{Ba}}$ & $51.71 \pm 0.89^{\mathrm{Ba}}$ & $54.48 \pm 0.79^{\mathrm{Aa}}$
\end{tabular}

Net Changes in Control Group

$\begin{array}{llll}G_{1}-G_{0} & 1.07 \pm 0.01^{f} & 0.98 \pm 0.19^{f} & 2.02 \pm 0.07^{b} \\ G_{2}-G_{0} & 0.46 \pm 0.31^{\mathrm{g}} & 1.18 \pm 0.45^{\mathrm{e}} & 3.43 \pm 0.55^{\mathrm{a}} \\ \mathrm{G}_{2}-\mathrm{G}_{1} & 1.53 \pm 0.32^{\mathrm{c}} & 0.20 \pm 0.64^{\mathrm{h}} & 1.41 \pm 0.48^{\mathrm{d}}\end{array}$

HPL Group

$\begin{array}{llll}\text { Gho } & 30.01 \pm 0.27^{\mathrm{Aa}} & 28.70 \pm 0.84^{\mathrm{ABb}} & 26.77 \pm 0.27^{\mathrm{Cb}} \\ G_{h 1} & 30.12 \pm 0.31^{\mathrm{Ca}} & 36.82 \pm 0.98^{\mathrm{Ba}} & 40.18 \pm 0.64^{\mathrm{Ba}} \\ G_{h 2} & 30.34 \pm 0.76^{\mathrm{Ca}} & 38.39 \pm 0.63^{\mathrm{Ba}} & 45.46 \pm 0.90^{\mathrm{Aa}}\end{array}$

Net Changes in HPL Group

\begin{tabular}{llll}
$G_{h 1}-G_{h 0}$ & $0.11 \pm 0.04^{\mathrm{g}}$ & $8.12 \pm 0.14^{\mathrm{d}}$ & $13.41 \pm 0.37^{\mathrm{b}}$ \\
$G_{h 2}-G_{h 0}$ & $0.33 \pm 0.49^{\mathrm{g}}$ & $9.69 \pm 0.21^{\mathrm{c}}$ & $18.69 \pm 0.63^{\mathrm{a}}$ \\
$G_{h 2}-G_{h 1}$ & $0.22 \pm 0.45^{\mathrm{g}}$ & $1.57 \pm 0.35^{\mathrm{f}}$ & $5.28 \pm 0.26^{\mathrm{e}}$ \\
\hline
\end{tabular}

Mean \pm Standard Deviation; $n=10$

$\mathrm{G}_{0}$ : Control Normal rat group. $\mathrm{G}_{1}$ : Normal rat group fed on $125 \mathrm{mg}$ bael leaf extract. $\mathrm{G}_{2}$ : Normal rat group fed on $250 \mathrm{mg}$ bael leaf extract $G_{h 0}$ : Control Hyperlipidemic rat group. $G_{h 1}$ : Hyperlipidemic rat group fed on $125 \mathrm{mg}$

bael leaf extract. $G_{h 2}$ : Hyperlipidemic rat group fed on $250 \mathrm{mg}$ bael leaf extract HPL: Hyperlipidemic group of rats

Means showing different lower case letters $(a, b, c, d, e, f, g)$ represent significant differences $(p<0.05)$ within control or HPL groups. Whereas, means showing different upper case letters $(A, B, C)$ represent significant differences $(p<0.05)$ across day-0 through day-60

minerals, crude fiber and energy rich source of available carbohydrates, dietary fiber and also contain antinutrients, which help in controlling cholesterol. Another study reported that bael leaf powder had 10 . $30 \mathrm{~g}$ ash [26]. The proximate composition of wild variety of bael leaves (Gir Forest) and cultivated variety (Gomayasi) Gujarat, India) were studied and it was found that both varieties had good nutritional components, however, the wild variety was superior to the cultivated variety in nutrients, such as carbohydrates, protein, fiber, moisture, ash content [27].

Phytochemical screening of ethanolic extract of bael leaf has been shown to reveal the presence of alkaloids [28]. The alkaloids content was quantitatively estimated and was found in the range of $3.78 \pm 0.15$ to $16.08 \pm 0$. $05 \mathrm{mg} / \mathrm{g}$ in different varieties of bael leaves [29]. Similarly, all the varieties exhibited good quantity of flavonoids and phenols starting from $10.40 \pm 0.047 \mathrm{mg} / \mathrm{mL}$ and $5.80 \pm 0.085 \mathrm{mg} / \mathrm{mL}$, respectively [30].

According to the findings of Muralidharan et al. [31] no significant body weight changes were found in rats fed on bael leaf extract. Increase in body weight of rats fed on basal diet in 60-day trial was normal [32].
Table 4 LDL of various groups of rats in 60 days study trial

\begin{tabular}{|c|c|c|c|}
\hline \multirow[t]{2}{*}{ Rat Groups } & \multicolumn{3}{|l|}{$\mathrm{LDL}(\mathrm{mg} / \mathrm{dL})$} \\
\hline & Day-0 & Day-30 & Day-60 \\
\hline \multicolumn{4}{|l|}{ Control } \\
\hline $\mathrm{G}_{0}$ & $134.10 \pm 2.13^{\mathrm{Ab}}$ & $134.24 \pm 2.44^{\mathrm{aB}}$ & $134.24 \pm 2.40^{\mathrm{Aa}}$ \\
\hline $\mathrm{G}_{1}$ & $141.69 \pm 2.72^{\mathrm{Aa}}$ & $138.23 \pm 2.5^{\mathrm{Ab}}$ & $134.66 \pm 2.35^{\mathrm{Ac}}$ \\
\hline $\mathrm{G}_{2}$ & $138.71 \pm 2.19^{\mathrm{Aa}}$ & $132.34 \pm 2.55^{\mathrm{Bb}}$ & $125.34 \pm 2.20^{B C}$ \\
\hline \multicolumn{4}{|c|}{ Net Changes in Control Group } \\
\hline$G_{1}-G_{0}$ & $7.59 \pm 0.59^{b}$ & $3.99 \pm 0.06^{\mathrm{e}}$ & $0.42 \pm 0.05^{h}$ \\
\hline$G_{2}, G_{0}$ & $4.61 \pm 0.06^{d}$ & $1.90 \pm 0.11^{\mathrm{g}}$ & $8.90 \pm 0.20^{\mathrm{a}}$ \\
\hline$G_{2}-G_{1}$ & $2.98 \pm 0.53^{f}$ & $5.89 \pm 0.05^{c}$ & $9.32 \pm 0.15^{a}$ \\
\hline \multicolumn{4}{|l|}{ HPL Group } \\
\hline$G_{\text {ho }}$ & $140.07 \pm 2.70^{\mathrm{aC}}$ & $164.55 \pm 2.79^{A b}$ & $186.68 \pm 3.39^{\mathrm{Aa}}$ \\
\hline$G_{h 1}$ & $143.25 \pm 2.05^{\mathrm{aA}}$ & $120.24 \pm 2.15^{\mathrm{Bb}}$ & $95.56 \pm 1.34^{B C}$ \\
\hline$G_{h 2}$ & $143.33 \pm 2.13^{\mathrm{aA}}$ & $114.44 \pm 2.11^{\mathrm{Cb}}$ & $79.32 \pm 1.98^{C c}$ \\
\hline \multicolumn{4}{|c|}{ Net Changes in HPL Group } \\
\hline$G_{h 1}-G_{h 0}$ & $3.18 \pm 0.65^{9}$ & $44.31 \pm 0.64^{d}$ & $91.12 \pm 2.05^{b}$ \\
\hline$G_{h 2}-G_{h 0}$ & $3.26 \pm 0.57^{9}$ & $50.11 \pm 2.11^{c}$ & $107.36 \pm 1.41^{a}$ \\
\hline$G_{h 2}-G_{h 1}$ & $0.08 \pm 0.07^{h}$ & $5.80 \pm 0.04^{f}$ & $16.24 \pm 0.64^{e}$ \\
\hline
\end{tabular}

Mean \pm Standard Deviation; $n=10$

$\mathrm{G}_{0}$ : Control Normal rat group. $\mathrm{G}_{1}$ : Normal rat group fed on $125 \mathrm{mg}$ bael leaf extract. $\mathrm{G}_{2}$ : Normal rat group fed on $250 \mathrm{mg}$ bael leaf extract $G_{h o}$ : Control Hyperlipidemic rat group. $G_{h 1}$ : Hyperlipidemic rat group fed on $125 \mathrm{mg}$

bael leaf extract. $G_{h 2}:$ Hyperlipidemic rat group fed on $250 \mathrm{mg}$ bael leaf extract HPL: Hyperlipidemic group of rats

Means showing different lower case letters $(a, b, c, d, e, f, g, h)$ represent significant differences $(p<0.05)$ within control or HPL groups. Whereas, means showing different upper case letters $(A, B, C)$ represent significant differences $(p<0.05)$ across day-0 through day-60

Umbelliferone (a benzopyrone present in Bael) possesses antihyperlipidemic effect and decreased the level of total cholesterol, very low-density lipoprotein cholesterol, LDL cholesterol, triglycerides, free fatty acids and phospholipids in the plasma, liver and kidneys of diabetic rats. It also increased the levels of HDL in plasma of rats [33]. This activity of bael leaf may maintain the body weight near to normal level.

Bael leaves are reported to contain coumarines, umbelliferone and esculetin which can increase the process of lipolysis [34]. The levels of serum total cholesterol and triglycerides were found to be significantly reduced in the bael extract treated diabetic animals. This might be due to the reduced hepatic triglyceride synthesis and or reduced lipolysis bael extract treated rats. The HDL levels increased significantly in the bael extract treated rats indicating a reversed atherogenic risk [35].

The lipid lowering activity of bael leaf extract may be attributed to the phytoconstituents present such as saponins and phenolic ingredients present in it as reported for other plant extracts [36]. Umbelliferone (a benzopyrone present in bael) possesses antihyperlipidemic properties and decreased the level of total cholesterol, very 
Table 5 Free Cholesterol of various groups of rats in 60 days study trial

\begin{tabular}{|c|c|c|c|}
\hline \multirow[t]{2}{*}{ Rat Groups } & \multicolumn{3}{|c|}{ Free Cholesterol (mg/dL) } \\
\hline & Day-0 & Day-30 & Day-60 \\
\hline \multicolumn{4}{|l|}{ Control } \\
\hline $\mathrm{G}_{0}$ & $20.34 \pm 0.13^{\mathrm{Bb}}$ & $21.29 \pm 0.44^{\mathrm{Aa}}$ & $21.88 \pm 0.40^{\mathrm{Aa}}$ \\
\hline $\mathrm{G}_{1}$ & $22.02 \pm 0.72^{\mathrm{Aa}}$ & $20.20 \pm 0.23^{B b}$ & $18.38 \pm 0.30^{B C}$ \\
\hline $\mathrm{G}_{2}$ & $21.52 \pm 0.95^{\mathrm{Aab}}$ & $19.38 \pm 0.38^{\mathrm{Cb}}$ & $17.42 \pm 0.48^{\mathrm{Cc}}$ \\
\hline \multicolumn{4}{|c|}{ Net Changes in Control Group } \\
\hline$G_{1}-G_{0}$ & $1.68 \pm 0.59^{d}$ & $1.09 \pm 0.21^{f}$ & $3.50 \pm 0.10^{b}$ \\
\hline$G_{2}-G_{0}$ & $1.18 \pm 0.82^{e}$ & $1.91 \pm 0.06^{c}$ & $4.46 \pm 0.08^{a}$ \\
\hline$G_{2}-G_{1}$ & $0.5 \pm 0.23^{i}$ & $0.82 \pm 0.15^{h}$ & $0.96 \pm 0.18^{9}$ \\
\hline \multicolumn{4}{|l|}{ HPL Group } \\
\hline $\mathrm{G}_{\text {ho }}$ & $24.51 \pm 1.38^{\mathrm{cb}}$ & $27.08 \pm 0.96^{\mathrm{Ab}}$ & $30.21 \pm 0.76^{\mathrm{Aa}}$ \\
\hline$G_{h 1}$ & $27.00 \pm 1.53^{\mathrm{Aa}}$ & $23.02 \pm 1.46^{\mathrm{Bb}}$ & $20.34 \pm 1.51^{B C}$ \\
\hline$G_{h 2}$ & $25.81 \pm 0.91^{\mathrm{Aa}}$ & $22.22 \pm 1.33^{\mathrm{Bab}}$ & $18.93 \pm 1.06^{\mathrm{BC}}$ \\
\hline \multicolumn{4}{|c|}{ Net Changes in HPL Group } \\
\hline$G_{h 1}-G_{h 0}$ & $2.49 \pm 0.15^{\mathrm{e}}$ & $4.06 \pm 0.50^{d}$ & $9.87 \pm 0.75^{\mathrm{b}}$ \\
\hline$G_{h 2}-G_{h 0}$ & $1.30 \pm 0.47^{f}$ & $4.86 \pm 0.37^{c}$ & $11.28 \pm 0.30^{\mathrm{a}}$ \\
\hline$G_{h 2}-G_{h 1}$ & $1.19 \pm 0.62^{f}$ & $0.80 \pm 0.13^{9}$ & $1.41 \pm 0.45^{f}$ \\
\hline
\end{tabular}

Mean \pm Standard Deviation; $n=10$

$\mathrm{G}_{0}$ : Control Normal rat group. $\mathrm{G}_{1}$ : Normal rat group fed on $125 \mathrm{mg}$ bael leaf extract. $\mathrm{G}_{2}$ : Normal rat group fed on $250 \mathrm{mg}$ bael leaf extract $\mathrm{G}_{\mathrm{h} 0}$ : Control Hyperlipidemic rat group. $\mathrm{G}_{\mathrm{h} 1}$ : Hyperlipidemic rat group fed on $125 \mathrm{mg}$

bael leaf extract. $\mathrm{G}_{\mathrm{h} 2}$ : Hyperlipidemic rat group fed on $250 \mathrm{mg}$ bael leaf extract HPL: Hyperlipidemic group of rats

Means showing different lower case letters $(a, b, c, d, e, f, g, h, i)$ represent significant differences $(p<0.05)$ within control or HPL groups. Whereas, means showing different upper case letters $(A, B, C)$ represent significant differences $(p<0.05)$ across day-0 through day- 60

low-density lipoprotein cholesterol, LDL cholesterol, triglycerides, free fatty acids and phospholipids in the plasma, liver and kidneys of diabetic rats. It also increased the levels of HDL in plasma of rats, which can also maintain the body weight closer to normal level [33].

In a study conducted by Suriyamoorthy et al. [7], there was a significant increase in the free cholesterol $(66.5 \%)$ and ester cholesterol levels (535.24\%) in oil induced group compared to that of the normal group. Treatment with herbal drugs like bael showed a significant decrease in the free cholesterol $(-17.65 \%)$ and ester cholesterol levels (-59.87\%). Free and ester cholesterol reduced significantly on treating the HFD rats with methanolic extract of Ipomoea digitata [37] and this supports the antioxidant activity of this herb. In our experiment we also got similar results that the ester cholesterol and free cholesterol were significantly increased in the cholesterol induced rats when compared to control. This elevated level of cholesterol was due to the deposition of hepatic cholesterol as a result of administration of cholesterol. Upon
Table 6 Ester Cholesterol of various groups of rats in 60 days study trial

\begin{tabular}{clcl}
\hline Rat Groups & \multicolumn{3}{l}{ Ester Cholesterol $(\mathrm{mg} / \mathrm{dL})$} \\
\cline { 2 - 4 } & Day-0 & Day-30 & Day-60 \\
\hline Control & & \\
$G_{0}$ & $2.20 \pm 0.06^{\mathrm{BC}}$ & $2.46 \pm 0.25^{\mathrm{AAB}}$ & $2.60 \pm 0.18^{\mathrm{Aa}}$ \\
$G_{1}$ & $2.50 \pm 0.15^{\mathrm{Ab}}$ & $2.26 \pm 0.19^{\mathrm{Ab}}$ & $1.95 \pm 0.08^{\mathrm{BC}}$ \\
$G_{2}$ & $2.69 \pm 0.19^{\mathrm{Aa}}$ & $2.38 \pm 0.38^{\mathrm{Ab}}$ & $2.09 \pm 0.12^{\mathrm{BC}}$
\end{tabular}

Net Changes in Control Group

$\begin{array}{llll}G_{1}-G_{0} & 0.30 \pm 0.09^{c} & 0.20 \pm 0.06^{d} & 0.65 \pm 0.10^{\mathrm{a}} \\ G_{2}-G_{0} & 0.49 \pm 0.13^{\mathrm{b}} & 0.08 \pm 0.13^{\mathrm{g}} & 0.51 \pm 0.06^{\mathrm{b}} \\ G_{2}-G_{1} & 0.19 \pm 0.04^{\mathrm{e}} & 0.12 \pm 0.19^{\mathrm{f}} & 0.14 \pm 0.04^{\mathrm{f}}\end{array}$

HPL Group

$\begin{array}{llll}G_{h 0} & 3.55 \pm 0.11^{\mathrm{Cb}} & 5.80 \pm 0.16^{\mathrm{Ab}} & 8.47 \pm 0.26^{\mathrm{Aa}} \\ G_{h 1} & 3.52 \pm 0.23^{\mathrm{Aa}} & 2.87 \pm 0.51^{\mathrm{Ab}} & 2.29 \pm 0.32^{\mathrm{BC}} \\ G_{h 2} & 3.94 \pm 0.35^{\mathrm{Aa}} & 2.59 \pm 0.35^{\mathrm{Bb}} & 1.58 \pm 0.15^{\mathrm{Cc}}\end{array}$

Net Changes in HPL Group

\begin{tabular}{llll}
$G_{h 1}-G_{h 0}$ & $0.03 \pm 0.12^{h}$ & $2.93 \pm 0.35^{d}$ & $6.18 \pm 0.06^{b}$ \\
$G_{h 2}-G_{h 0}$ & $0.39 \pm 0.24^{f}$ & $3.21 \pm 0.19^{c}$ & $6.89 \pm 0.11^{a}$ \\
$G_{h 2}-G_{h 1}$ & $0.42 \pm 0.12^{f}$ & $0.28 \pm 0.16^{9}$ & $0.71 \pm 0.17^{\mathrm{e}}$ \\
\hline
\end{tabular}

Mean \pm Standard Deviation; $n=10$

$G_{0}$ : Control Normal rat group. $G_{1}$ : Normal rat group fed on $125 \mathrm{mg}$ bael leaf extract. $G_{2}$ : Normal rat group fed on $250 \mathrm{mg}$ bael leaf extract $G_{h o}$ : Control Hyperlipidemic rat group. $G_{h 1}$ : Hyperlipidemic rat group fed on $125 \mathrm{mg}$

bael leaf extract. $G_{h 2}$ : Hyperlipidemic rat group fed on $250 \mathrm{mg}$ bael leaf extract HPL: Hyperlipidemic group of rats

Means showing different lower case letters $(a, b, c, d, e, f, g, h)$ represent significant differences $(p<0.05)$ within control or HPL groups. Whereas, means showing different upper case letters $(A, B, C)$ represent significant differences $(p<0.05)$ across day-0 through day- 60

treatment with the bael, the cholesterol level was reduced back to near normal level. It was also evident that the treatment with the extract of bael leaf inhibited the significant elevation of total cholesterol as compared to that of dyslipidemic animals [38].

\section{Conclusions}

It is quite evident from this study that bael contains a number of phytoconstituents which reveals its uses for various therapeutic purposes against hyperlipidemia like metabolic syndrome. Bael leaf extract supplementation decreased total cholesterol, total triglyceride, LDL, HDL, free and ester cholesterol. Therefore, we suggest that active components of bael have a significant antihyperlipidemic effect. Limitations of this study are that the investigation was performed only on male rats, therefore, we cannot exclude the possibility that sex influences the effect of bael leaf extract on hypercholesterolemia or hyperlipidemia and survival mechanisms. Still, so much work is required with the bael to investigate the mechanism of actions with other therapeutic activities. 


\section{Acknowledgements}

Specials thanks are extended to Dr. Muhammad Siddiq, guide of this project and Dr. Kirk. D Dolan at Michigan State University to encouragement to successfully complete the work. The authors are highly obliged to the Department of Food Science, Nutrition and Home Economics, Government College University Faisalabad (GCUF). Authors thanks the Library Department, Michigan State University and IT Department, Higher Education Commission (HEC) for access to journals, books and valuable database.

\section{Funding}

This work was supported by the Department of Food Science, Nutrition and Home Economics, Government College University Faisalabad and Higher Education Commission, Islamabad, Pakistan.

\section{Availability of data and materials}

The dataset supporting the conclusions of this article is included within the article.

\section{Authors' contributions}

NA conceptualized and performed the study; ZM, MUA and RSA provided the technical assistance and guided in the data collection; $\mathrm{Ml}$ and $\mathrm{SMH}$ helped to analyze the data and drafting the manuscript. All authors read and approved the final manuscript.

\section{Competing interest}

The authors declare that they have no competing interests.

\section{Ethics approval and consent to participate}

The study program was designed after the review and approval of ethical guidelines set by parent institute.

\section{Consent for publication}

Not Applicable.

\section{Publisher's Note}

Springer Nature remains neutral with regard to jurisdictional claims in published maps and institutional affiliations.

\section{Author details}

'Department of Food Science, Nutrition and Home Economics, Government College University, Faisalabad, Pakistan. ${ }^{2}$ Institute of Home and Food Sciences, Faculty of Life Sciences, Government College University, Faisalabad, Pakistan. ${ }^{3}$ Department of Zoology, Wild life and Fisheries, Government College University Faisalabad, Faisalabad, Pakistan.

\section{Received: 31 May 2017 Accepted: 21 March 2018}

Published online: 03 April 2018

\section{References}

1. Sharma GN, Dubey SK, Sharma P, Sati N. Medicinal values of Bael (Aegle marmelos) (L.) Corr.: a review. Int J Cur Pharm Rev Res. 2011;1(3):12-22.

2. Rout BN, Abhisek AP, Upadhyay R. Effect of aqueous extract of Aegle marmelos (Bael leaves) on perfused toads heart. Int J Health Sci Res. 2016; 6(2):182-8.

3. Dhankar S, Ruhil S, et al. Aegle marmelos (Linn.): a potential source of phytomedicine. J Med Plant Res. 2011;5(9):1947-507.

4. Axay PR, Dipak G, Monodeep C, Jagdish KV. Aegle marmelos (Linn.): a therapeutic bone for human health. Int J Res Ayurveda Pharm. 2012;3(2): 159-63.

5. Urvi PR, Priyanka CR, Lambole V, Gajera V, Dhiren PS. Pharmacological activities of Aegle marmelos: An Overview. Pharma Sci Monitor. 2016;7(2):98-106.

6. Patel PK, Sahu J, Sahu L, Prajapati NK, Dubey BK. Aegle marmelos: a review on its medicinal properties. Int J Pharm Phytopharmacol Res. 2012;1(5):332-41.

7. Suriyamoorthy P, Fathima RMM, Subrhamanian H, Kanagasapabathy D. Anti hyperlipidemic effect of aqueous extract of Aegle marmelos and camellia sinensis in oil fed hyperlipidemic rats. Int J Pharm Pharm Sci. 2014;6(2):338-41.

8. Jadeja ARN, Thounaojam MC, Patel V, Devkar RV, Ramachandran AV. Antihyperlipidemic potential of a polyherbal preparation on triton WR 1339 (Tyloxapol) induced hyperlipidemia: a comparison with lovastatin. Int J Green Pharm. 2009;3:119-24.
9. Sinha S, Ghosh AK. Hypolipidemic effect of ethanolic extract of Aegle marmelos and terminalia arjuna in hyperlipidemic rat model. Int J Adv Tech Engr Sci. 2015;3(2):616-21.

10. Narayanasamy R, Leelavinothan P. In-vivo and in-vitro antioxidant activities of coumarin on chemical induced hyperglycemic rats. Int J Pharma Sci Res. 2011;2(4):968-78.

11. Kamalakkannan N, Stanely PMP. Hypoglycemic effect on water extracts of Aegle marmelos fruits in streptozotocin diabetic rats. J Ethnopharmacol. 2003;87:207-10.

12. Vijaya C, Ramanathan M, Suresh B. Lipid lowering activity of ethanolic extract of Aegle marmelos (Linn.) in hyperlipidemic models of wistar albino rats. Indian J Exp Biol. 2009;47:182-5.

13. Gohil T, Pathak N, Jivani N, Devmurari $V$, Patel J. Treatment with extracts of Eugenia jambolana seed and Aegle marmelos leaf extracts prevents hyperglycemia and hyperlipidemia in alloxan induced diabetic rats. African $J$ Pharm Pharma. 2010;4(5):270-5.

14. AACC. Approved methods of American Association of Cereal Chemists. 10th ed. St. Paul, Minnesota: The American Association of Cereal Chemists, Inc.; 2000.

15. AOAC. Official methods of analysis. 18th ed. VA, USA: The Association of the Official Analytical Chemists. Arlington; 2006.

16. Harborne JB. Methods of plant analysis. In: Phytochemical methods. Netherlands: Springer; 1973. p. 1-35.

17. Singleton VL, Orthofer R, Lamuela-raventos RM. Analysis of total phenols and other oxidation substrates and antioxidants by means of FolinCiocalteu reagent. Methods Enzymol. 1999;299:152-78.

18. Wolf BW, Weisbrode SE. Safety evaluation of an extract from Salacia oblonga. Food Chem Toxicol. 2003;41:867-74.

19. Uchida K, Satoh T, Ogura Y, Yamaga N, Yamada K. Effect of partial ileal bypass on cholesterol and bile acid metabolism in rats. Yanago Acta Medica. 2001:44:69-77.

20. Stockbridge $H$, Hardy Rl, Glueck CJ. Photometric determination of cholesterol (CHOD-PAP method). Ecoline ${ }^{\circledR}$ 2S, Merck KGaA, 64271 Darmstadt, Germany. J Lab Clin Med. 1989;114(2):142-51.

21. Assmann G. HDL-cholesterol precipitant. Randox labs. Ltd. Crumlin co. Antrim, N. Ireland. Internist. 1979;20:559-64.

22. McNamara JR, Cohn JS, Wilson PW, Schaefer EJ. Calculated values for lowdensity lipoprotein cholesterol in the assessment of lipid abnormalities and coronary disease risk. Clin Chem. 1990;36:36-42.

23. Annoni G, Botasso BM, Ciaci D, Donato MF, Tripodi A. Liquid triglycerides (GPO-PAP). J Lab Clin Med. 1982:9:115.

24. Mukherjie KL. Mechanism of liver in kwashiorkor- a review. Indian pediat. 1965;2:1-9.

25. Steel RGD, Torrie JH, Dickey D. Principles and procedures of statistics, a biometrical approach. 3. New York: McGraw Hill Book Co Inc, USA; 1997.

26. Singh U, Kocher A, Boora R. Proximate composition, available carbohydrates, dietary fibres and anti-Nutritional factors in Bael (Aegle marmelos L.) leaf, pulp and seed powder. Int J Sci Res Pub. 2012;2(4):1-4.

27. Nigam V, Nambiar VS. Evaluation of the physico-chemical characteristics, minerals and heavy metals in wild and cultivated variety of Aegle marmelos (L) Correa leaves. J Ayuv Herb Med. 2014;4(6):1634-48.

28. George M, Joseph L, Sreelakshmi R. Phytochemical and pharmacological screening of in vivo anti-inflammatory activity of Aegle marmelos (L.) Corr. Serr. J Chem Pharm Res. 2016:8(2):330-4.

29. Mujeeb F, Bajpai P, Pathak N. Phytochemical evaluation, antimicrobial activity, and determination of bioactive components from leaves of Aegle marmelos. Hindawi Publish Corp BioMed Res Int. 2014:497606. https://doi.org/10.1155/2014/49760.

30. Kumar KS, Asish GR, Mony RS, Sundaresan A, Venugopalan W. Comparative evaluation of the antioxidant and antidiabetic activity of different parts of Aegle marmelos and its chemical profiling using hplc and hptlc technique. World J Pharm Pharm Sci. 2015;4(09):1107-21.

31. Muralidharan L. Beneficial effects of Aegle marmelos leaves on blood glucose levels and body weight changes in alloxan- induced diabetic rats. J Med Plants Stud. 2014;2(4):46-9.

32. Pillai S, Muralidharan L. Beneficial effects of Aegle marmelos leaves on blood glucose levels and body weight changes in alloxan-induced diabetic rat. $J$ Diabetes Metab. 2012:3:8.

33. Ramesh B, Pugalendi KV. Antioxidant role of umbelliferone in STZ-diabetic rats. Life Sci. 2006:79:306-10.

34. Mukherjee K, Biswas R, Chaudhary SK, Mukherjee PK. Botanicals as medicinal food and their effect against obesity. In: Mukherjee K, editor. Evidence based validation of herbal medicine. Amsterdam: Elsevier; 2015. p. 373-403. 
35. Pandey S. Treatment of diabetes and hyperlipidemia with extracts of Eugenia jambolana seed and Aegle marmelos leaf extracts in alloxan induced diabetic rats. Int J Pharma and Bio Sci. 2010;6(2):1-10.

36. Andrew P. Triterpenoids and saponins. In: The constituents of medicinal plants. Wallingford: CABI Publishing; 2004. p. 73-84.

37. Muthu KA, Alagumanivasagam G, Satheesh KD, Manavalan R. Effect of Methanolic extract of tuberous root of Ipomoea Digitata (Linn) on hyperlipidemia induced by rat fed with high fat diet. Res J Pharma Biol Chem Sci. 2011;2(3):183-91.

38. Manjunatha $\mathrm{H}$, Srinivasan $\mathrm{K}$. Hypolipidemic and antioxidant effects of Aloe in high fat-fed rats. Can J Physiol Pharmacol. 2007:85:588-96.

Submit your next manuscript to BioMed Central and we will help you at every step:

- We accept pre-submission inquiries

- Our selector tool helps you to find the most relevant journal

- We provide round the clock customer support

- Convenient online submission

- Thorough peer review

- Inclusion in PubMed and all major indexing services

- Maximum visibility for your research

Submit your manuscript at www.biomedcentral.com/submit
Biomed Central 